\title{
Analysis of $\gamma$-Aminobutyric Acid Content in Fermented Plant Products by HPLC/UV
}

\author{
Dong Gu Lee $\cdot$ Sunghun Cho $\cdot$ Jamin Lee $\cdot$ Seon Haeng Cho · Sanghyun Lee* $\mathbb{D}$
}

Received: 12 June 2015 / Accepted: 21 August 2015 / Published Online: 31 December 2015

(C) The Korean Society for Applied Biological Chemistry 2015

\begin{abstract}
Aminobutyric acid (GABA) content in fermented plant products and their main plant materials (aerial part of Acanthopanax sessiliflorus, fruit of Crataegus pinnatifida, and whole plant of Morus alba) was determined by high-performance liquid chromatography. GABA was quantified using a reversephase column with a gradient elution program (water:acetonitrile $=90: 10$ to $0: 100$ for $40 \mathrm{~min}$ ). UV detection was conducted at 280 $\mathrm{nm}$. GABA content was measured in fermented plant products (15.07 mg/g), aerial part of A. sessiliflorus $(4.49 \mathrm{mg} / \mathrm{g})$, fruit of $C$. pinnatifida $(10.59 \mathrm{mg} / \mathrm{g})$, and whole plant of $M$. alba $(2.31 \mathrm{mg} / \mathrm{g})$. The presence of GABA in fermented plant products, including $A$. sessiliflorus, C. pinnatifida, and M. alba is important in industrial application for health supplements.
\end{abstract}

Keywords Acanthopanax sessiliflorus · constituent · $\gamma$-Aminobutyric acid $\cdot$ industrial application

\section{Introduction}

Acanthopanax sessiliflorus belongs to the family Araliaceae, and it is used as a traditional medicine in Korea, China, Japan, and Manchuria (Lee, 1979). A. sessiliflorus is widely used as an herbal medicine because of its anti-tumor, anti-inflammatory, analgesic,

D. G. Lee $\cdot$ S. Cho $\cdot$ J. Lee $\cdot$ S. Lee

Department of Integrative Plant Science, Chung-Ang University, Anseong 17546, Republic of Korea

\section{S. H. Cho}

Gongju National University of Education, Gongju 32553, Republic of Korea

*Corresponding author (S. Lee: slee@cau.ac.kr)

This is an Open Access article distributed under the terms of the Creative Commons Attribution Non-Commercial License (http://creativecommons. org/licenses/by-nc/3.0/) which permits unrestricted non-commercial use, distribution, and reproduction in any medium, provided the original work is properly cited. and immunostimulatory activities. It is used in the treatment of cardiovascular and cerebrovascular diseases (Lee, 1979; Zhou, 1985; Lee et al., 2003; Song et al., 2011). The root bark of $A$. sessiliflorus is widely used for treating rheumatism, reinforcing kidney function, strengthening bones, and promoting blood circulation (Song et al., 2012b). In addition, the roots have various analgesic, anti-inflammatory, anti-pyretic, and diuretic activities (Brekhman and Dardymov, 1969; Shohael et al., 2005). Several constituents such as lignin, asarinin, sesamin, helioxanthin, and savinin have been isolated from the roots (Zhang et al., 2003). Quercetin, a pharmacologically and therapeutically effective compound, was isolated from the fruits (Zhu et al., 2013). In Korea and some other Asian countries, many beverages and tablets contain A. sessiliflorus. Recently, consumption of $A$. sessiliflorus has been increasing dramatically (Zhao et al., 2001).

Crataegus pinnatifida belongs to the family Rosaceae (locally called hawthorn), and it is widely distributed in Europe, North America, and northeastern part of China (Edwards et al., 2012). $C$. pinnatifida has been widely used as a medicinal and food material in China and the European countries (Fong and Bauman, 2002). To date, more than 160 compounds have been isolated from $C$. pinnatifida, including flavonoids, terpenes, lignans, and organic acids (Ahn et al., 1998; Edwards et al., 2012; Song et al., 2012a; Huang et al., 2013; Liu et al., 2013; Sendker et al., 2013). The leaves of $C$. pinnatifida are widely used for heart problem, such as declining cardiac performance, deficiency in coronary blood supply, and mild forms of arrhythmia (Pöpping et al., 1995; Al Makdessi et al., 1996).

Morus alba is a deciduous tree that belongs to the family Moraceae, and it is widely cultivated in tropical, subtropical, and temperate regions (Agarwal and Kanwar, 2007). M. alba has been used in East Asia as an herbal medicine for healing various diseases, such as lung-heat, cough, hematemesis, dropsy, beriberi, dysuria, and it has anti-inflammatory, anti-viral, and anti-tumor activities (Zhou and Li, 1997; Zhishen et al., 1999; Nam et al., 2002; Shi et al., 2001; Du et al., 2003; Park et al., 2003).

$\gamma$-Aminobutyric acid (GABA) is a non-protein amino acid that is widely distributed in nature and acts as a major inhibitory 
neurotransmitter in the central nervous system (Manyam et al., 1981; Abdou et al., 2006). GABA is known to have hypotensive, diuretic, and tranquilizing effects. GABA intake could also help treat various neurological disorders, such as seizures, Parkinson's disease, stiff-man syndrome, and schizophrenia (Shin and Lee, 2002; Aoki et al., 2003; Oh et al., 2003; Hayakaw et al., 2004; Oh and $\mathrm{Oh}, 2004)$. GABA has various biological activities, so it is an important compound. Many studies have analyzed triterpenoids, lignans, and phenylpropanoids in plants, including those belonging to Acanthopanax (Jakobs et al., 1993; Inoue et al., 2003; Wong et al., 2003; Jin et al., 2004; An et al., 2008; Kim et al., 2012), but few studies have analyzes GABA content in plant materials.

In this study, GABA content in fermented plant products, including aerial part of $A$. sessiliflorus, fruit of $C$. pinnatifida, and whole plant of $M$. alba was analyzed using high-performance liquid chromatography (HPLC).

\section{Materials and Methods}

Plant materials. Aerial parts (leaf, stem, and fruit) of $A$. sessiliflorus, fruit of $C$. pinnatifida, and whole plant (leaf, stem, and root) of $M$. alba were cultivated in and collected from Gongju, Korea, and they have identified by Prof. S. H. Cho, Gongju National University of Education, Korea.

Preparation of fermented plant products. Fermented plant products were prepared using traditional methods; these products were composed up of 12 types of plant materials (aerial part of $A$. sessiliflorus, $12 \%$; fruit of $C$. pinnatifida, $8 \%$; whole plant of $M$. alba, 8\%; sprout of Phyllostachys bambusoides, 8\%; fruit of Benincasa hispida, 8\%; sprout of Brassica oleracea, $8 \%$; sprout of Rhaphanus sativus, 8\%; aerial part of Venanthe japonica, 7\%; aerial part of Sedum sarmentosum, 7\%; root of Phragmites longivalvis, 7\%; fruit of Quercus acutissima, 2\%; and sprout of Pinus densiflora, 2\%), mineral water (8\%), malt sugar (3\%), and honey (5\%).

Chemicals and equipment. HPLC-grade solvents such as acetonitrile $(\mathrm{ACN})$, methanol $(\mathrm{MeOH})$, and distilled water $\left(\mathrm{H}_{2} \mathrm{O}\right)$ were purchased from J. T. Baker ${ }^{\mathbb{B}}$ (USA), and GABA (Fig. 1) was purchased from Sigma-Aldrich (USA). Evaporation was conducted using an evaporator system (Eyela rotary system, Japan) under reflux in vacuo. HPLC was performed using a Waters Breeze system (Waters Co., USA) equipped with a Waters 1525 binary HPLC pump and a 2489 system UV/VIS detector.

Sample preparation. To analyze GABA in fermented plant products and their main plant materials, $20 \mathrm{~g}$ of each sample was extracted with $100 \% \mathrm{MeOH}(3 \times 100 \mathrm{~mL})$ under reflux and evaporated in vacuo. The residue was dissolved in $1 \mathrm{~mL}$ of $\mathrm{H}_{2} \mathrm{O}$ and filtered with a $0.45-\mu \mathrm{m}$ filter. The resulting solution was used for HPLC analysis.

HPLC conditions. HPLC of GABA for qualitative and quantitative analyses was performed using a reverse phase system. An INNO ${ }^{\mathbb{R}}$ C18 $(4.6 \times 250 \mathrm{~mm}, 5 \mu \mathrm{m})$ column was used with a mobile phase<smiles>NCCCC(=O)O</smiles>

Fig. 1 Chemical structure of GABA.

that consisted of $\mathrm{H}_{2} \mathrm{O}$ and $\mathrm{ACN}$. A gradient solvent system of $\mathrm{H}_{2} \mathrm{O}$ and $\mathrm{ACN}$ (90:10 to 0:100 for $40 \mathrm{~min}$ ) was used for the elution program. UV detection was conducted at $280 \mathrm{~nm}$. The injection volume was $10 \mu \mathrm{L}$, and the flow rate was $1 \mathrm{~mL} / \mathrm{min}$. All injections were performed in triplicate.

Limit of detection and limit of quantification. Validation of the HPLC method with GABA as the standard was performed using limit of detection (LOD) and limit of quantification (LOQ). The linearity of the method was established by triplicate injections in the range of $0.015-0.5 \mathrm{mg} / \mathrm{mL}$. Standard calibration solutions were prepared at seven different concentration levels $(0.5,0.25,0.15$, $0.125,0.0625,0.0312$, and $0.015 \mathrm{mg} / \mathrm{mL}$ ) and injected in triplicate. Calibration curves were constructed by linear regression of the peak area-ratios (Y) of GABA versus the concentration (X) in mg/ $\mathrm{mL}$; relative standard deviation was used as a measure of repeatability. Percent recoveries were evaluated by calculating the ratio of the amount detected versus the amount added. The values of LOD and LOQ were determined separately at a signal to noise ratio (S/ N) of 3 and 10, respectively.

Calibration curve. A stock solution $(1 \mathrm{mg} / \mathrm{mL})$ of GABA was prepared in water, and then successively diluted to $50 \%$ to create different concentrations. Analyte content was determined from the corresponding calibration curves. The calibration functions of GABA were calculated using the peak area $(Y)$, concentration (X, $\mu \mathrm{g} / 10 \mu \mathrm{L}$ ), and mean values $(\mathrm{n}=3) \pm$ standard deviation (SD).

High resolution LC/MS-MS. LC/MS-MS analysis was performed in a 5600 Q-TOF LC/MS/MS system (AB Sciex, USA) using a Ultimate 3000 RSLC HPLC system (Dionex, USA), including a degasser, an autosampler, diode array detector, and a binary pump. The LC separation was performed on a Hypersil GOLD column $(2.1 \times 50 \mathrm{~mm}, 1.9 \mu \mathrm{m}$, Thermo Scientific, USA $)$ with a mobile phase A $(0.1 \%$ formic acid in water) and a mobile phase B $(0.1 \%$ formic acid in acetonitrile). The flow rate was $0.25 \mathrm{~mL} / \mathrm{min}$. The linear gradient was as follows: $0-4 \mathrm{~min}, 99 \% \mathrm{~A} ; 4.1-8.0 \mathrm{~min}, 50 \%$ $\mathrm{A}$; and $8.1-13.0 \mathrm{~min}, 5 \% \mathrm{~A}$. The autosampler was set at $5^{\circ} \mathrm{C}$. The injection volume was $100 \mu \mathrm{L}$. Mass spectra were acquired under positive electrospray ionization with an ion spray voltage of -4500 V. The source temperature was $450^{\circ} \mathrm{C}$. The curtain gas, ion source gas 1 , and ion source gas 2 were 35,65 , and 55 psi, respectively.

Table 1 Calibration curve for GABA

\begin{tabular}{|c|c|c|c|}
\hline Name & $t_{R}$ & Calibration equation $^{a}$ & Correlation factor, $r^{2}$ \\
\hline GABA & 35.76 & $\mathrm{Y}=1226.5 \mathrm{X}-749.25$ & 0.9909 \\
\hline
\end{tabular}

${ }^{\mathrm{a}} \mathrm{Y}=$ Peak area, $\mathrm{X}=$ Concentration of standards $(\mathrm{mg} / \mathrm{mL})$.

$\mathrm{b} r^{2}=$ Correlation coefficient for three data points from the calibration curve. 
(A)

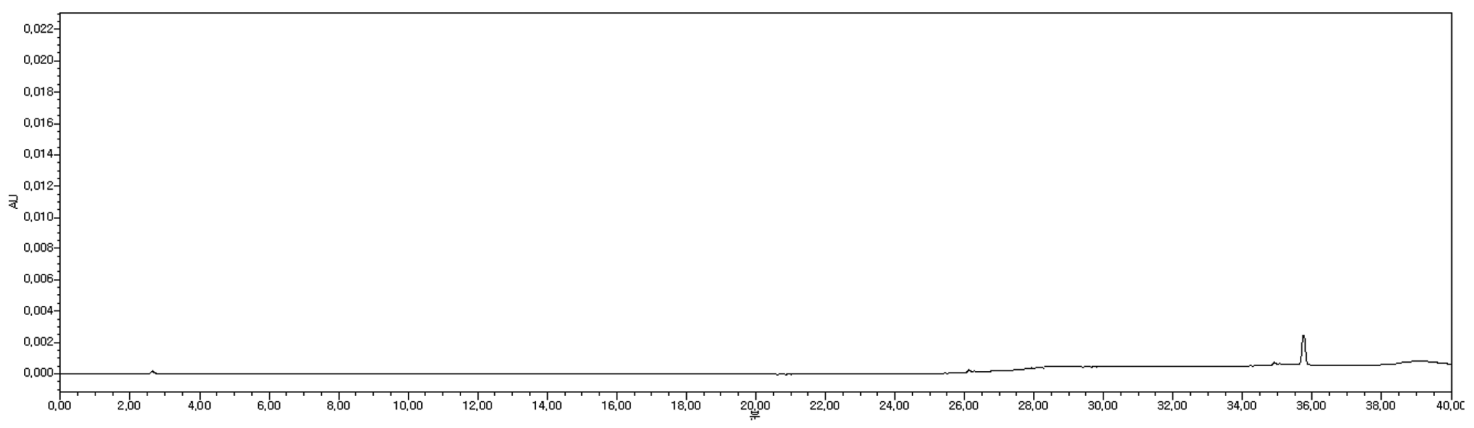

(B)

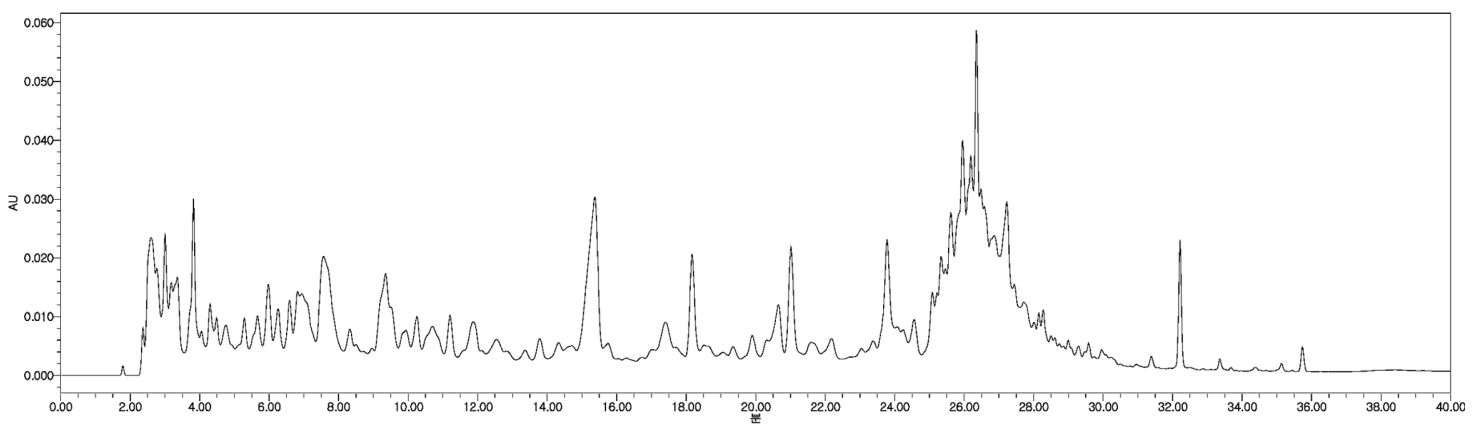

(C)

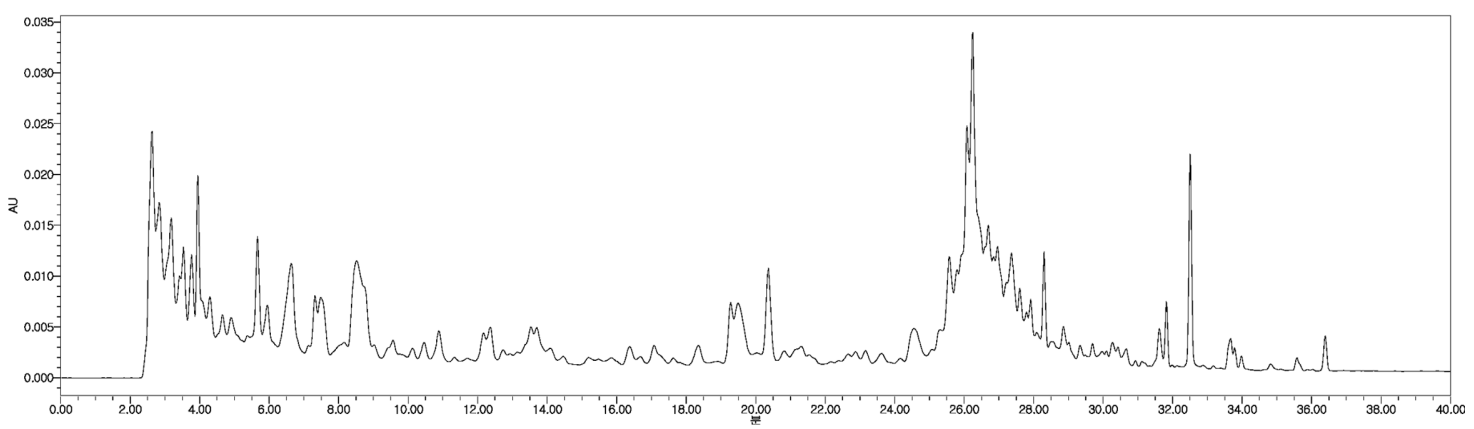

(D)

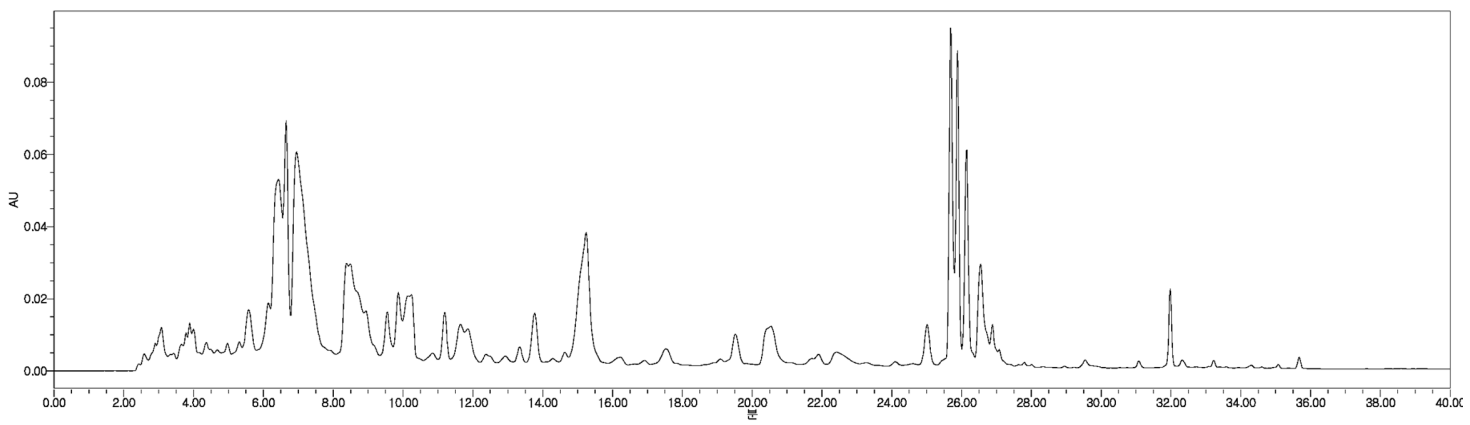

(E)

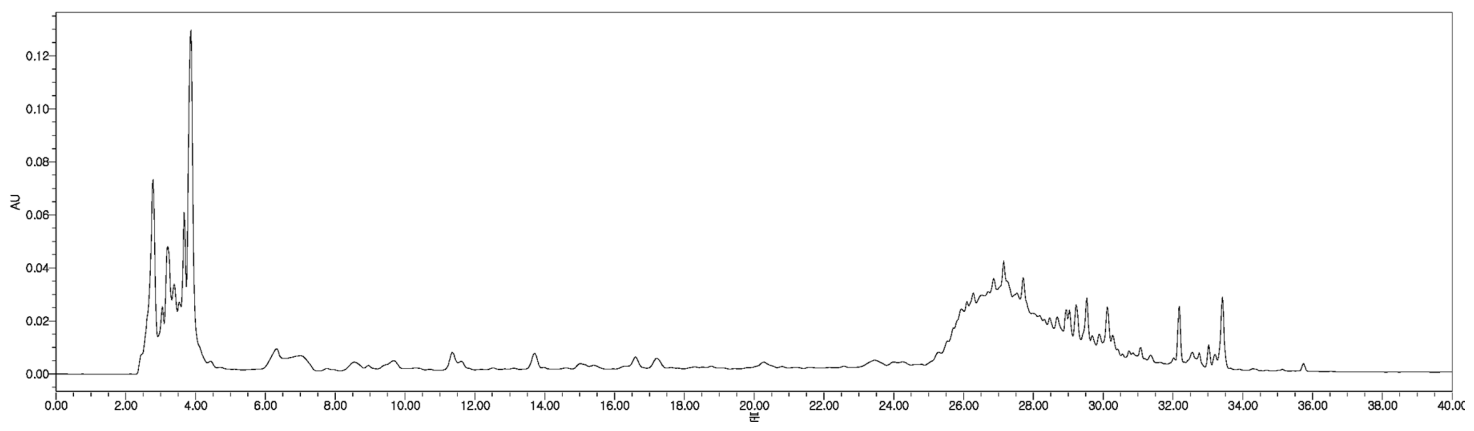

Fig. 2 HPLC chromatograms of GABA (A), fermented plant products (B), aerial part of A. sessiliflorus (C), fruit of C. pinnatifida (D), and whole plant of $M$. alba (E). 
(A)

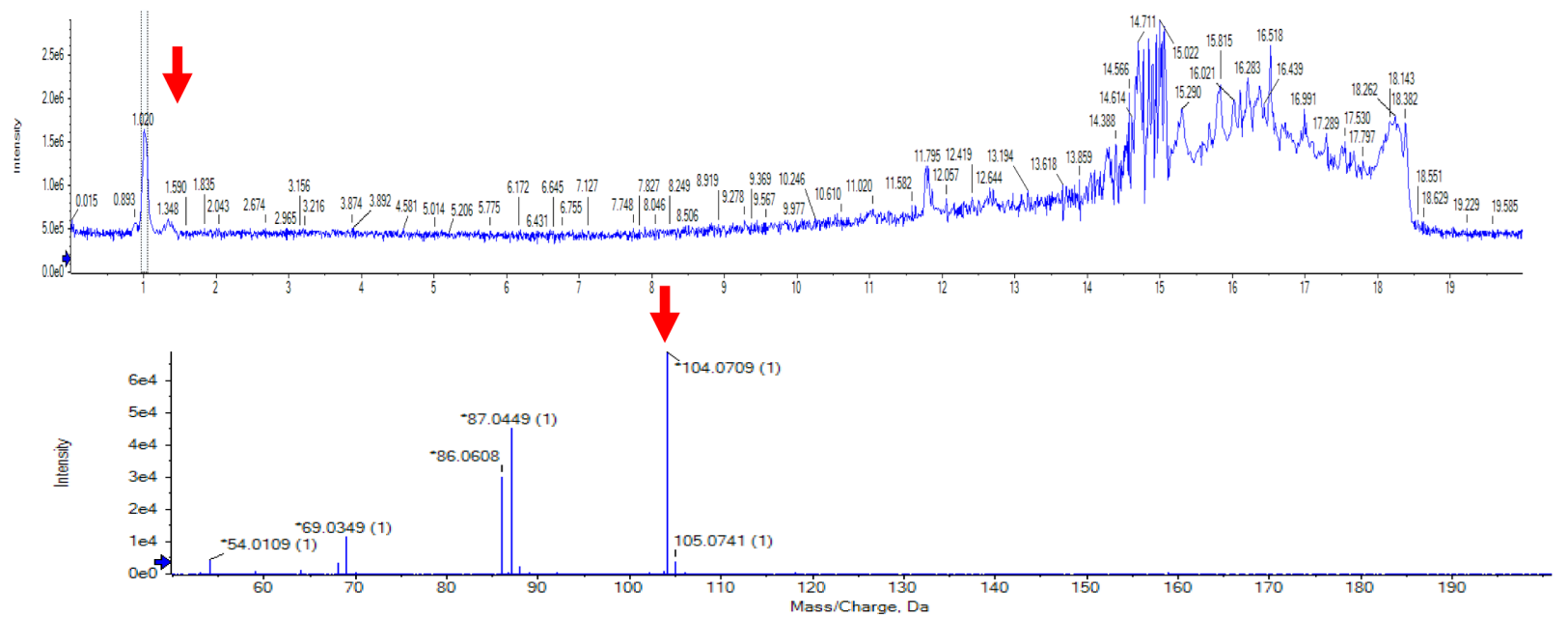

(B)
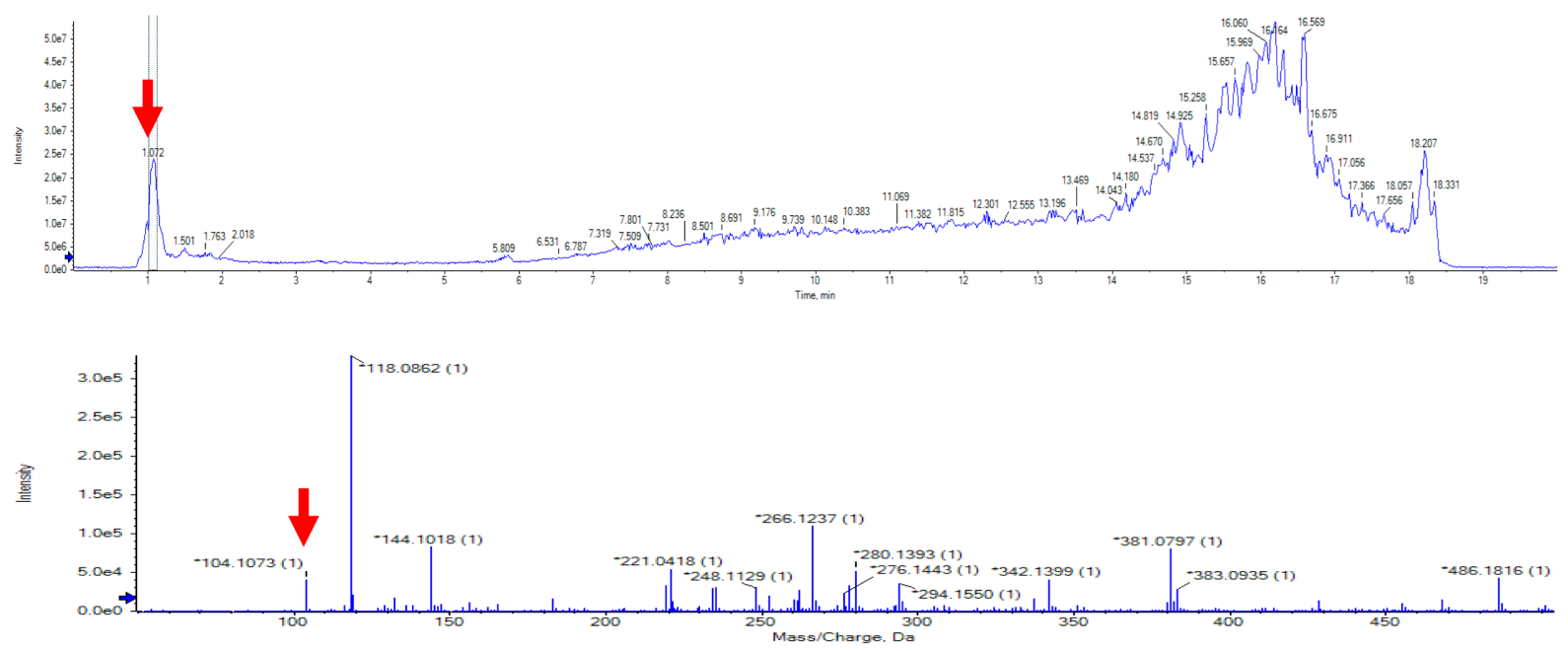

(C)
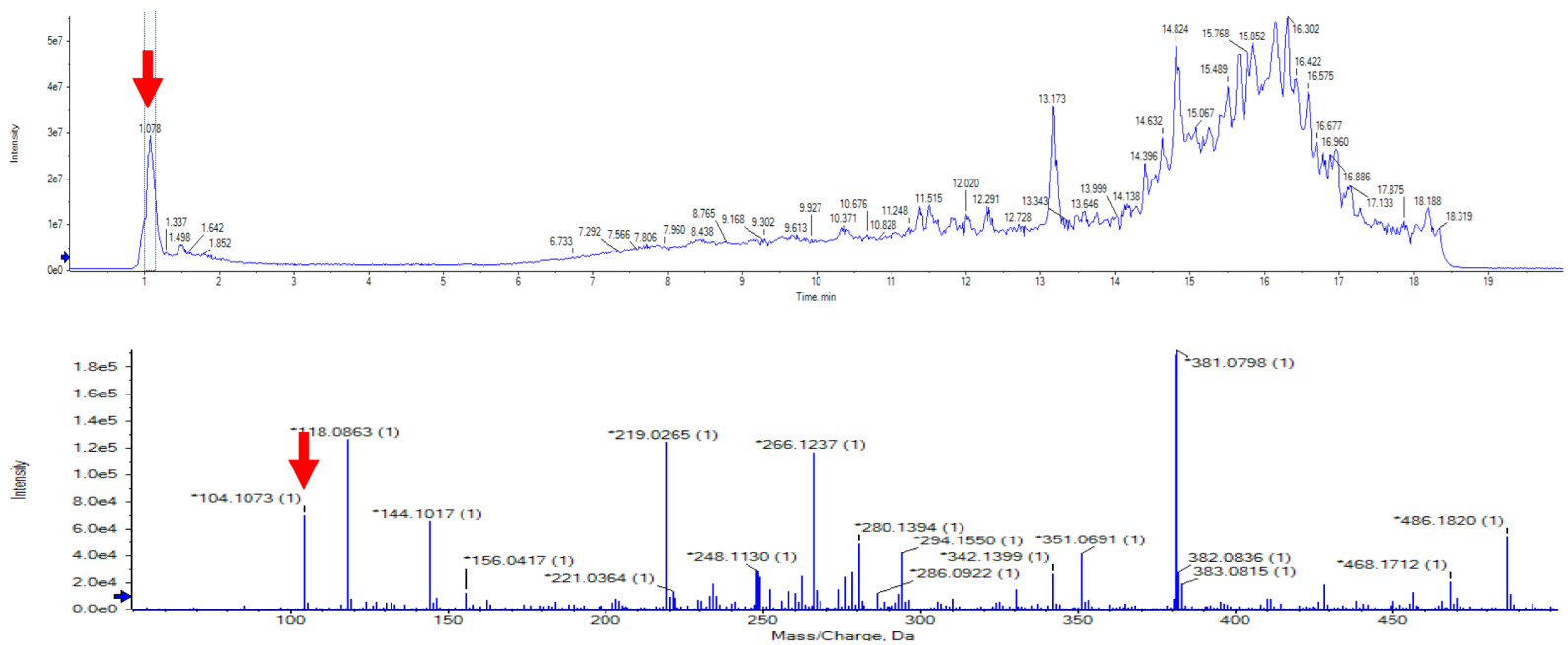

Fig. 3 LC/MS-MS chromatograms of GABA (A), fermented plant products (B), aerial part of A. sessiliflorus (C), fruit of C. pinnatifida (D), and whole plant of M. alba (E). 
(D)
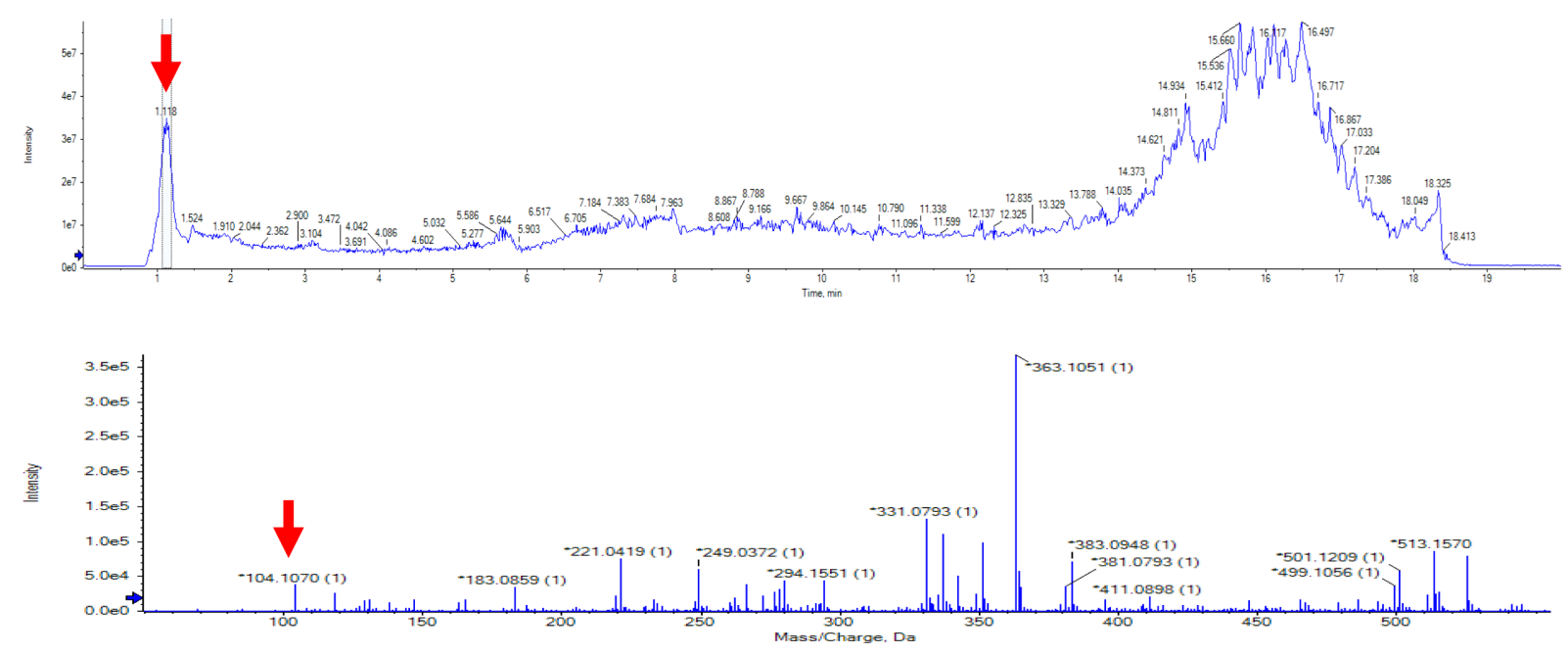

(E)
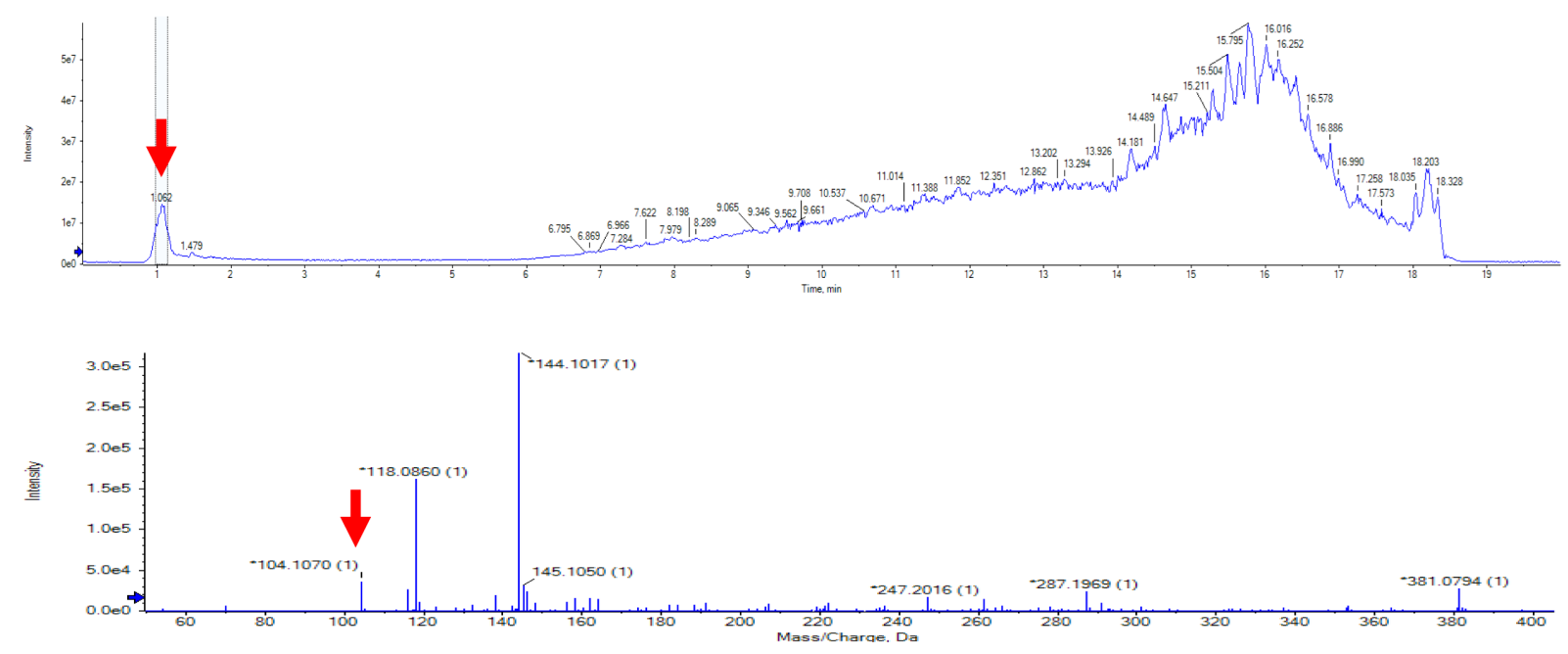

Fig. 3 Continued.

\section{Results and Discussion}

Qualitative and quantitative analyses of GABA content in fermented plant products and their main plant materials (aerial part of $A$. sessiliflorus, fruit of $C$. pinnatifida, and whole plant of M. alba) were performed using HPLC with a reverse phase system. The retention time for GABA was $35.76 \mathrm{~min}$. The HPLC conditions used in the analysis showed good linearity for the five standard GABA solutions $\left(r^{2}=0.9909\right)$ (Table 1). The calibration equation and retention time are shown in Table 1. GABA content in the fermented plant products, aerial part of $A$. sessiliflorus, fruit of $C$. pinnatifida, and whole plant of $M$. alba was determined on the basis of material specifications. The HPLC chromatograms of the fermented plant products, aerial part of $A$. sessiliflorus, fruit of C. pinnatifida, and whole plant of $M$. alba (100\% MeOH extracts) are shown in Fig. 2. The optimized electrospray ionization condition should be sensitive enough to GABA with positive ion detection mode. The collision-induced dissociation of the precursor ion $[\mathrm{M}]^{+}$at $\mathrm{m} / z 104$ resulted in the neutral loss of ammonia and the formation of the product ions at $m / z 87$ (Fig. 3). Using an optimized analytical method, GABA content in the fermented plant products ( $15.07 \mathrm{mg} / \mathrm{g}$ ), aerial part of $A$. sessiliflorus (4.49 mg/g), fruit of $C$. pinnatifida $(10.59 \mathrm{mg} / \mathrm{g})$, and whole plant of $M$. alba $(2.31 \mathrm{mg} / \mathrm{g})$ was successfully and simultaneously determined (Table 2). Our results showed that maxium GABA content was found in the fermented plant products $(15.07 \mathrm{mg} / \mathrm{g})$.

LOD and LOQ values were determined at signal to-noise ratios $(\mathrm{S} / \mathrm{N})$ of 3 and 10, respectively. LOD and LOQ values for ten

Table 2 GABA content in fermented plant products and their main plant materials

\begin{tabular}{lc}
\hline \multicolumn{1}{c}{ Sample } & Content $(\mathrm{mg} / \mathrm{g})$ \\
\hline Fermented plant products & $15.07 \pm 2.03$ \\
Aerial part of A. sessiliflorus & $4.498 \pm 0.630$ \\
Fruit of C. pinnatifida & $10.59 \pm 0.95$ \\
Whole plant of M. alba & $2.31 \pm 0.49$ \\
\hline
\end{tabular}

Data are the mean $\pm \mathrm{SD}(n=4)$ in $\mathrm{mg} / \mathrm{g}$ of the dried samples. 
Table 3 LOD and LOQ for GABA

\begin{tabular}{cccccc}
\hline Name & Regression equation $^{\mathrm{a}}$ & $r^{{ }^{\mathrm{b}}}$ & Linear range $(\mathrm{mg} / \mathrm{mL})^{\mathrm{LOOD}(\mathrm{mg} / \mathrm{mL})}$ & $\mathrm{LOQ}(\mathrm{mg} / \mathrm{mL})$ \\
\hline GABA & $\mathrm{Y}=185.35 \mathrm{X}+10.972$ & 0.9995 & $0.015-0.5$ & 0.103 & 0.357 \\
\hline
\end{tabular}

${ }^{\mathrm{a}} \mathrm{Y}=$ Peak area, $\mathrm{X}=$ Concentration of standards $(\mathrm{mg} / \mathrm{mL})$.

$\mathrm{b} r^{2}=$ Correlation coefficient for three data points from the calibration curve.

marker compounds were determined by performing ten injections of each compound at concentrations that incrementally approached LOD and LOQ. The LOD and LOQ values of the ten analytes ranged from 0.103 to $0.357 \mathrm{mg} / \mathrm{mL}$, respectively (Table 3). It is very significant that GABA, which is widely used as a health supplement, has been identified in the fermented plant products, aerial part of $A$. sessiliflorus, fruit of $C$. pinnatifida, and whole plant of $M$. alba.

GABA has several biological activities, such as hypertensive, diuretic, and tranquilizing effects (Shin and Lee, 2002; Aoki et al., 2003; Oh et al., 2003; Wong et al., 2003; Hayakaw et al., 2004; $\mathrm{Oh}$ and $\mathrm{Oh}, 2004)$. GABA is widely found in bacteria and higher plants, such as tea, rice, and soybean (Tsushida et al., 1987; Komassuzaki et al., 2005; Wang et al., 2010). Recently, GABA tea has become popular in Taiwan. GABA tea is a special tea enriched with GABA by anaerobic conditions of fresh tea-leaves (Tsushida et al., 1987). GABA content in the tea was found to be $1.734 \mathrm{mg} / \mathrm{g}$ (Lin et al., 2012). Maoyecha tea has shown that the amount of GABA could be increased by repeated treatment of bacteria sequence fermentation. After the treatment, GABA content was significantly increased (Tsushida et al., 1987; Huang et al., 2011).

In conclusion, the presence of GABA in the fermented plant products, including aerial part of $A$. sessiliflorus, fruit of $C$. pinnatifida, and whole plant of $M$. alba is important in agricultural crop production for increasing the amounts of clinically available medicine and health supplements. The inherent selectivity and sensitivity of the LC/MS-MS with electrospray ionization makes this analytical method potentially applicable to the detection and quantification of GABA in other food products (Zazzeroni et al., 2009). In addition, GABA content in the fermented plant products is higher than that in GABA tea and Maoyecha tea. Therefore, the fermented plant products can potentially be used as materials for manufacturing GABA products.

Acknowledgments This study was performed with the support of Gongju National University of Education (School Enterprise) Sillyok, Republic of Korea. The authors thank the staff and crew of the National Center for InterUniversity Research Facilities (Seoul National University) for their assistance with the NMR and GC/MS experiments.

\section{References}

Abdou AM, Higashiguchi S, Horie K, Kim M, Hatta H, and Yokogoshi H (2006) Relaxation and immunity enhancement effects of gammaaminobutyric acid (GABA) administration in humans. Biofactors 26, 201-8.

Agarwal S and Kanwar K (2007) Comparison of genetic transformation in
Morus alba L. via different regeneration systems. Plant Cell Rep 26, $177-85$.

Ahn KS, Hahm MS, Park EJ, Lee HK, and Kim IH (1998) Crosolic acid isolated from fruit Crataegus pinnatifida var. pilosa is protein kinase $\mathrm{C}$ inhibitor as well as a cytotoxic agent. Planta Med 64, 468-70.

Al Makdessi S, Sweidan H, Müllner S, and Jocob R (1996) Myocardial protection by pretreatment with Crataegus oxycantha: An assessment by means of the release of lactate dehydrogenase by the ischemic and reperfused Langendorff heart. Arzneimitt Forsch 46, 25-7.

An Q, Yang CJ, Song Y, Yu K, Xiong ZL, and Li FM (2008) Studies on the chemical constituents of the fruit of Acanthopanax sessiliflorus (Rupr. et Maxim.) Seem. Nat Prod Res Dev 20, 765-9.

Aoki H, Furuya Y, Endo Y, and Fujimoto K (2003) Effect of $\gamma$-aminobutyric acid-enriched tempeh-like fermented soybean (GABA-tempeh) on the blood pressure of spontaneously hypertensive rats. Biosci Biotechnol Biochem 67, 1806-8.

Brekhman II and Dardymov IV (1969) Substances of plant origin which increase nonspecific resistance. Annu Rev Pharmacol 9, 415.

Du J, He ZD, Jiang RW, Ye WC, Xu HX, and But PPH (2003) Antiviral flavonoids from the root bark of Morus alba L. Phytochemistry 62 , 1235-8.

Edwards JE, Brown PN, Talent N, Dickinson TA, and Shipley PR (2012) A review of the chemistry of the genus Crataegus. Phytochemistry 79, 526.

Fong HHS and Bauman JL (2002) Hawthorn in cardiovascular disease. $J$ Cardiovasc Nurs 16, 1-8.

Hayakaw K, Kimura M, Kasaha K, Matsumoto K, Sansawa H, and Yamori Y (2004) Effect of a $\gamma$-aminobutyric acid-enriched dairy product on the blood pressure of spontaneously hypertensive and normotensive WistarKyoto rats. British J Nutr 92, 411-7.

Huang LZ, Huang BK, Ye Q, and Qin LP (2011) Bioactivity-guided fractionation for anti-fatigue property of Acanthopanax senticosus. $J$ Ethnopharmacol 133, 213-9.

Huang XX, Guo DD, Li LZ, Lou LL, Li DM, Zhou CC et al. (2013) Monoterpene and sesquilignan compounds from the leaves of Crataegus pinnatifida. J Biochem. Syst Ecol 48, 1-5.

Inoue K, Shirai T, Ochiai H, Kasao M, Hayakawa K, Kimura M et al. (2003) Blood-pressure-lowering effect of a novel fermented milk containing $\gamma$ aminobutyric acid (GABA) in mild hypertensives. Eur J Clin Nutr 57, 490-5.

Jakobs C, Jaeken J, and Gibson KM (1993) Inherited disorders of GABA metabolism. J Inh Metab Dis 16, 704-5.

Jin JL, Lee S, Lee YY, Kim JM, Heo JE, and Choi HS (2004) Platelet antiaggregating triterpenoids from the leaves of Acanthopanax senticosus and the fruits of A. sessiliflorus. Planta Med 70, 564-6.

Kim HY, Lee DG, Lee KH, and Lee S (2012) Protective effects of 3,4-secolupane type triterpenes from Acanthopanax senticosus against advanced glycation endproducts. Hort Environ Biotechnol 53, 242-6.

Komassuzaki N, Shima J, Kawamoto S, Momose H, and Kimura T (2005) Production of $\gamma$-aminobutyric acid (GABA) by Lactobacillus paracasei isolated from traditional fermented foods. Food Microbiol 22, 497-504.

Lee SH, Lee YS, Jung SH, Ji J, Shin KH, Kim B-K et al. (2003) Antitumor and immunostimulating activities of Acanthopanax sessiliflorus fruits. Nat Prod Sci 9, 112-6.

Lee WT (1979) Distribution Acanthopanax plants in Korea. Kor J Pharmacol 10, 103-7.

Lin SH, Mau JL, and Hsu CA (2012) Bioactive components and antioxidants of tea leaves. Food Sci Technol 46, 64-70.

Liu FZ, Ren JW, Tang JS, Liu XZ, Che YS, and Yao XS (2013) 
Cyclohexanone derivatives with cytotoxicity from the fungus Penicillium commune. Fitoterapia 87, 78-83.

Manyam BV, Katz L, Hare TA, Kaniefski K, and Tremblay RD (1981) Isoniazidinduced elevation of cerebrospinal fluid (CSF) GABA levels and effects on chorea in huntington's disease. Ann Neurol 10, 35-7.

Nam SY, Yi HK, Lee JC, Kim JC, Song CH, Park JW et al. (2002) Cortex mori extract induces cancer cell apoptosis through inhibition of microtubule assembly. Arch Pharm Res 25, 191-6.

$\mathrm{Oh} \mathrm{CH}$ and $\mathrm{Oh} \mathrm{SH}$ (2004) Effects of germinated brown rice extracts with enhanced levels of GABA on cancer cell proliferation and apoptosis. $J$ Med Food 7, 19-23.

Oh SH, Soh JR, and Cha YS (2003) Germinated brown rice extract shows a nutraceutical effect in the recovery of chronic alcohol-related symptoms. $J$ Med Food 7, 115-21.

Park KM, You JS, Lee HY, Baek NI, Hwang JK, and Kuwanon G (2003) An antibacterial agent from the root bark of Morus alba against oral pathogens. J Ethnopharmacol 84, 181-5.

Pöpping S, Rose H, Ioneseu I, Fisher Y, and Kammermeier H (1995) Effect of a hawthorn extract on contraction and energy turnover of isolated rat cardiomyocytes. Arzneimitt Forsch 11, 1157-61.

Sendker J, Petereit F, Lautenschläger M, Hellenbrand N, and Hensel A (2013) Phenylpropanoid-substituted procyanidins and tentatively identified procyanidin glycosides from hawthorn (Crataegus spp.). Planta Med 79, $45-51$.

Shi YQ, Fukai T, Sakagami H, Chang WJ, Yang PQ, Wang FP et al. (2001) Cytotoxic flavonoids with isoprenoid groups from Morus mongolica. $J$ Nat Prod 64,181-8.

Shin KH and Lee S (2002) The chemistry of secondary products from Acanthopanax species and their pharmacological activities. Nat Prod Sci 8, 111-26.

Shohael AM, Chakrabarty D, Yu KW, Hahn EJ, and Paek KY (2005) Application of bioreactor system for large-scale production of Eleutherococcus sessiliflorus somatic embryos in an air-lift bioreactor and production of eleutherosides. J Biotechnol 120, 228-36.

Song SJ, Li LZ, Gao PY, Yuan YQ, Wang RP, Liu KC et al. (2012a) Isolation of antithrombotic phenolic compounds from the leaves of Crataegus pinnatifida. Planta Med 78, 1967-71.
Song Y, Deng Y, Huang D, Wen J, Liu Z, and Li F (2012b) LC-MS/MS determination and pharmacokinetic study of four lignin components in rat plasma after oral administration of Acanthopanax sessiliflorus extract. $J$ Ethnopharmacol 141, 957-63.

Song Y, Yang CJ, Yu K, and Li FM (2011) In vivo antithrombotic and antiplatelet activites of a quantified Acanthopanax sessiliflorus fruit extract. Chin J Nat Med 9, 0141-5.

Tsushida T, Murai T, Omori M, and Okamoto J (1987) Production of new type tea containing a high level of $\gamma$-aminobutyric acid. Nippon Nogeikagaku Kaishi 61, 817-22.

Wang JJ, Wang HY, and Shih CD (2010) Autonomic nervous system and nitric oxide in antihypertensive and cardiac Inhibitory effects Induced by red mold rice in spontaneously hypertensive rats. J Agric Food Chem $\mathbf{5 8}$, $7940-8$.

Wong CG, Bottiglieri T, and Snead OC (2003) GABA, gammahydroxybutyric acid, and neurological disease. Ann Neurol 54, 3-12.

Zazzeroni R, Homan A, and Thain E (2009) Determination of ã-aminobutyric acid in food matrices by isotope dilution hydrophilic interaction chromatography coupled to mass spectrometry. J Chromatogr Sci 47, 564-8.

Zhang LL, Guan ZZ, and Zhang JK (2003) Experimental study of the effects of Asarinin on Immunosuppression activity in vitro. Chin J Cardiol 31, 444-7.

Zhao M, Wang Y, and Kang L (2001) Study on activity of inner inhibitory substances of Acanthopanax senticosus (Rupr. et Maxim) harms fruits and seeds. China J Chin Mater Med 26, 534-8.

Zhishen J, Mengcheng T, and Jianming W (1999) The determination of flavonoid contents in mulberry and their scavenging effects on superoxide radicals. Food Chem 64, 555-9.

Zhou CC (1985) Anti-inflammatory action of ethanol extracts from Acanthopanax sessiliflorus. Zhong Yao Tong Bao 10, 37-41.

Zhou DW and Li CM (1997) The pharmacological activity of the root bark of Morus alba L. World Notes Plant Med 12, 155-7.

Zhu QG, Sujari ANA, and Ghani SA (2013) Nafion-MWCNT Composite Modified Graphite Paste for the Analysis of Quercetin in Fruits of Acanthopanax sessiliflorus. Sens Actuator B-Chem 177, 103-10. 